\section{Larval Attachment and Development of the Monogenean Neoheterobothrium hirame under Low Water Temperature}

\author{
Sho Shirakashi ${ }^{1}$, Tomoyoshi Yoshinaga ${ }^{1}$, \\ Masakazu Oka ${ }^{2}$ and Kazuo Ogawa ${ }^{1 *}$ \\ ${ }^{1}$ Department of Aquatic Bioscience, Graduate School of \\ Agricultural and Life Sciences, The University of \\ Tokyo, Tokyo 113-8657, Japan \\ ${ }^{2}$ Kamiura Station, National Center for Stock Enhancement, \\ Fisheries Research Agency, Oita 879-2602, Japan
}

(Received October 10, 2004)

ABSTRACT-Effects of low water temperature (below $10^{\circ} \mathrm{C}$ ) on the oncomiracidial attachment and its subsequent development of Neoheterobothrium hirame were investigated. The cumulative attached larvae to the gill pieces from olive flounder Paralichthys olivaceus was reduced by $30 \%$ at $5^{\circ} \mathrm{C}$ when compared with $20^{\circ} \mathrm{C}$. At $8^{\circ} \mathrm{C}$ the parasite development on flounder was significantly retarded compared at $20^{\circ} \mathrm{C}$, and considerable number of worms disappeared from the host before reaching maturation. These results suggest low water temperature is a factor limiting the population growth of $N$. hirame in cold temperature regions.

Key words: Neoheterobothrium hirame, Paralichthys olivaceus, water temperature, survival, development

The blood-feeding monogenean Neoheterobothrium hirame is a widespread parasite among olive flounder, Paralichthys olivaceus, in the Japanese waters ${ }^{1)}$. Although high prevalence of $N$. hirame infection has been observed in a wide geographical area, regional variability in the infection level has been observed ${ }^{1,2}$. Our ongoing field observations in Miyako Bay, Iwate and Obama Bay, Fukui also showed that infection level in Miyako was significantly lower than that in Obama. Miyako Bay is located in the northern Pacific coast of Japan, and the average annual water temperature in 2002 was $12.0^{\circ} \mathrm{C}$, with average water temperature during the winter months (December to March) of $5.6^{\circ} \mathrm{C}$. This made the water temperature in one third of a year below $10^{\circ} \mathrm{C}$. We hypothesize that such low water temperature is a factor limiting population growth of $N$. hirame. Although past studies have showed effects of water temperature on egg production ${ }^{3)}$, egg hatching

\footnotetext{
* Corresponding author

E-mail: aogawak@mail.ecc.u-tokyo.ac.jp
}

rate $^{4)}$, growth rate and survival ${ }^{5)}$ in $N$. hirame, there have been no report on the infection biology of $N$. hirame below $10^{\circ} \mathrm{C}$. Two laboratory experiments were conducted to quantify the larval attachment and the parasite development under low water temperature conditions.

\section{Materials and Methods}

\section{Collection of parasite eggs and oncomiracidia}

Neoheterobothrium hirame eggs were collected from a tank with infected olive flounder and incubated at $21^{\circ} \mathrm{C}$. Freshly hatched larvae were used for the following experiment.

\section{Larval attachment to host gills in vitro}

The attachment of oncomiracidia to the host at different temperatures was investigated in vitro, using gill pieces of juvenile olive flounder. To avoid contamination, antibiotics (Penicillin G potassium 100 units $/ \mathrm{mL}$, Streptomycin sulphate $1000 \mu \mathrm{g} / \mathrm{mL}$, Amphoterine B 25 $\mu \mathrm{g} / \mathrm{mL}$ ) were added to the larval suspension. The suspension was then stored at $5^{\circ} \mathrm{C}$ for $2 \mathrm{~h}$ to incorporate possible negative effects of temperature change onto the attachment by giving all the larvae an equal temperature shock. The suspension containing approximately 100 (97-103) larvae and a small piece of gill (ca. $4 \times 4 \mathrm{~mm}$ ) that were excised freshly from uninfected juvenile flounder were added into each well of 6 Well Microplate (Corning, USA). Each plate was stored at 5,10 or $20^{\circ} \mathrm{C}$ for $24 \mathrm{~h}$. Considering the degradation of the gill tissue, gill piece was replaced with a fresh one every three hours and numbers of larvae attached to the removed gill pieces were counted. Thus, total of seven gill pieces were used for each well. The cumulative attachment rate over $24 \mathrm{~h}$ among the three temperature treatments were compared at the end.

\section{Parasite development}

For the experimental infection, total of 80 juvenile olive flounder, mean total length $( \pm S D$, here and elsewhere otherwise stated) of $91 \pm 4.0 \mathrm{~mm}$, were exposed to 4,000 oncomiracidia (ca. 50 larvae per fish) at $18^{\circ} \mathrm{C}$. Fish were then randomly assigned to a rearing tank kept at 20 or $8^{\circ} \mathrm{C}$. Five fish from each tank were sampled at 10 or 15 day intervals, except for the last two samplings which were done at longer intervals. At each sampling, the following measurements and observations were conducted: total body length, body weight, haemoglobin content $(\mathrm{Hb})$ of the peripheral blood, coloration of the gills and internal organs, and parasite load. Worms found from the buccal cavity were considered as adults, and immature parasites on the gills were further categorized into the following five developmental stages based on the number of clamps; Stage 0: no obvious developed clamps, Stages I-IV: 1-4 pairs of clamps accordingly5). The experiment was terminated at 105 days post expo- 
sure $(\mathrm{PE})$.

\section{Statistical analyses}

The normality of the data was tested by ShapiroWilk test. The differences in total number of attached oncomiracidia among the three temperatures were tested using ANOVA followed by Tukey-Kramer HSD multiple comparison. The parasite densities and $\mathrm{Hb}$ between the two rearing temperatures were analysed using Wilcoxon rank sum test.

\section{Results and Discussion}

Although $N$. hirame oncomiracidia still maintained its infectivity at low water temperature, the cumulative attached rate was significantly affected by the tempera-

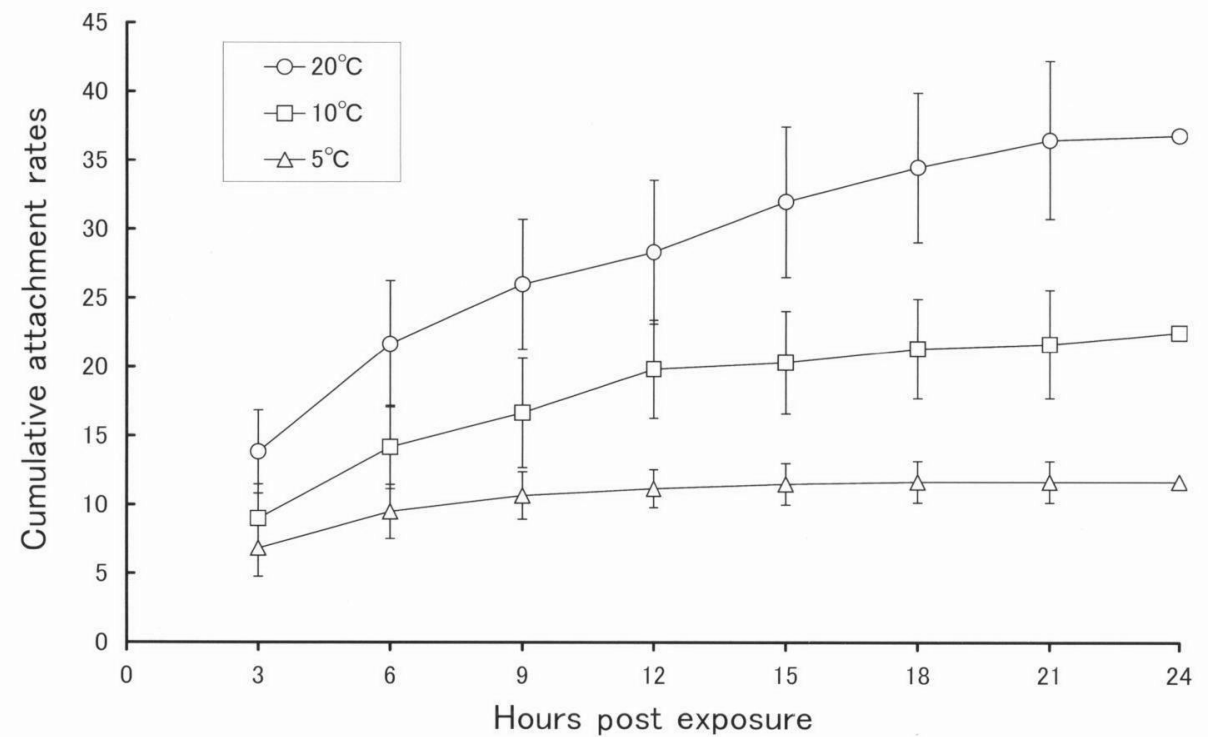

Fig. 1. Changes in average ( \pm SD) cumulative number of larvae attached to the gill pieces of olive flounder at 5,10 and $20^{\circ} \mathrm{C}$ over 24 hours. Approximately 100 larvae were placed in each well and each gill piece was exposed to larvae for 3 hours.

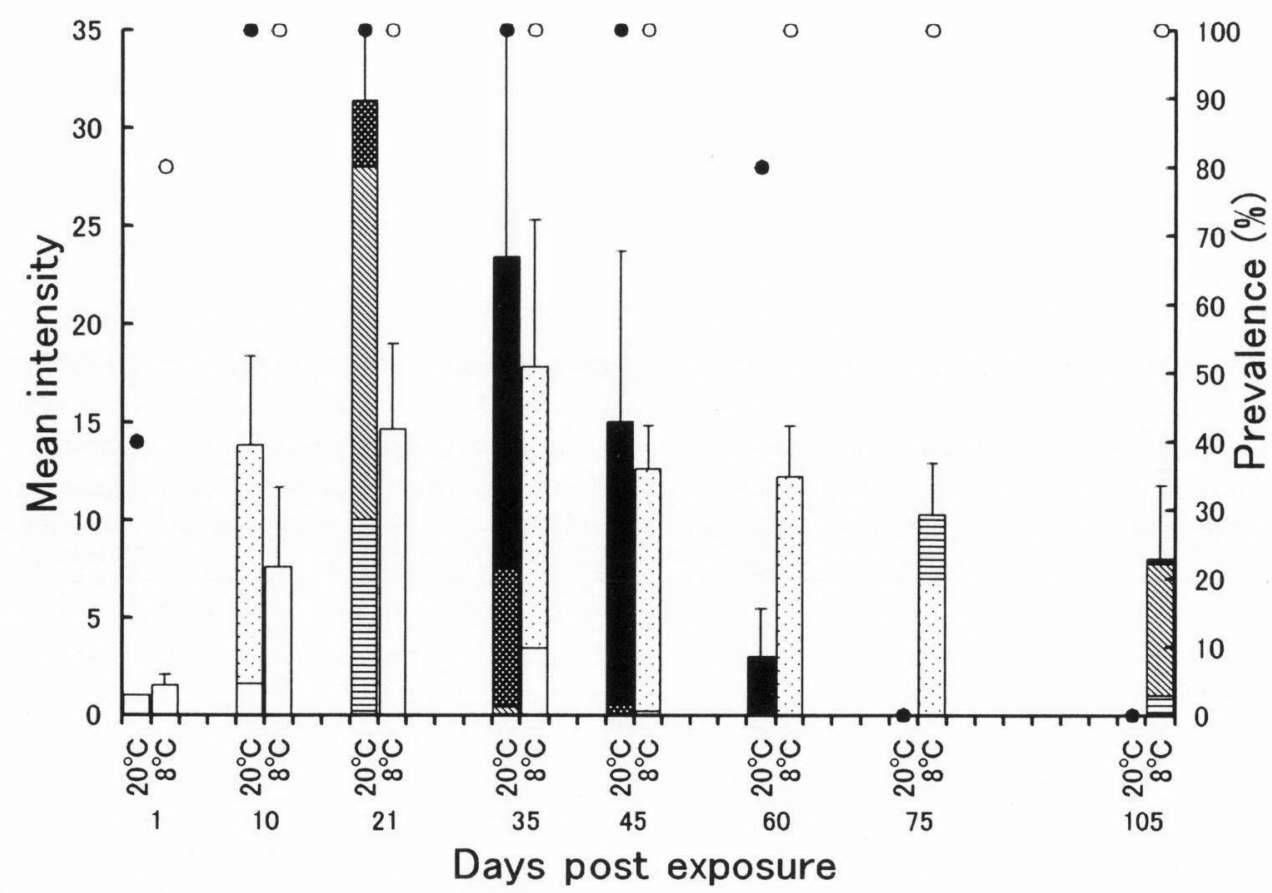

Fig. 2. Development of $\mathrm{N}$. hirame on experimentally infected juvenile olive flounder at $8^{\circ} \mathrm{C}$ and $20^{\circ} \mathrm{C}$. Adult refer to the worms inhabiting the buccal cavity, and Stage 0 and Stages I-IV refer to those with 0 and with 1-4 pairs of clamps, respectively. Bars indicate mean intensity $+\mathrm{SD}$. Closed circle and open circles indicate prevalence at $20^{\circ} \mathrm{C}$ and $8^{\circ} \mathrm{C}$, respectively. $\square$ Stage 0 , $\square$ Stage I, 目 Stage II, Stage III, Stage IV, Adult 
ture (ANOVA, $F_{2,17}=56.54, p<0.0001$; Fig. 1). The mean ratios of attached larvae after $24 \mathrm{~h}$ at 5,10 and $20^{\circ} \mathrm{C}$ were $11.7 \pm 1.50 \%, 22.5 \pm 3.94 \%$ and $36.8 \pm$ $5.74 \%$, respectively and were significantly different from each other (Tukey-Kramer HSD, $p<0.05$ ). The attachment rate at $5^{\circ} \mathrm{C}$ was less than $30 \%$ of that at $20^{\circ} \mathrm{C}$. Although the attachment rate may be underestimated as it was investigated in vitro using the gill pieces, the low attachment rate in lower water temperature groups strongly suggests the inhibition of $N$. hirame transmission among wild olive flounder in cold water regions.

Water temperature also had a strong influence on the development of $N$. hirame (Fig. 2). At $20^{\circ} \mathrm{C}$, adult worms were first observed at 35 days $\mathrm{PE}$, but no longer found at 75 days PE, probably because all the adults had died or dislodged. In contrast, the most advanced stage during the 105 days of experimental period at $8^{\circ} \mathrm{C}$ was only stage III. This indicates the drastic retardation in the parasite development. Moreover, at $8^{\circ} \mathrm{C}$, numbers of immature worms declined over time. Furthermore, the highest worm intensity observed at $8^{\circ} \mathrm{C}(17.8 \pm 7.5$ worms at 35 days $\mathrm{PE}$ ) was significantly lower than that at $20^{\circ} \mathrm{C}(31.4 \pm 7.3$ worms at 21 days $\mathrm{PE}$ ) (Wilcoxon, $Z=$ $-2.21, p=0.027$; Fig. 2). These results suggest that the immature parasites in the $8^{\circ} \mathrm{C}$ group had died or dislodged $^{6)}$ during the prolonged premature period. Such mortality of immature worms is probably due to the unsuitable low water temperature for $N$. hirame.

Haemoglobin contents in the fish reared at $20^{\circ} \mathrm{C}$ significantly fluctuated. At the beginning of the experiment, mean $\mathrm{Hb}$ was $3.8 \pm 1.1 \mathrm{~g} / 100 \mathrm{~mL}$, but fish showed anaemic symptoms at $35(1.5 \pm 1.5 \mathrm{~g} / 100 \mathrm{~mL})$ and 45 days $P E(0.2 \pm 0.04 \mathrm{~g} / 100 \mathrm{~mL})$. However, the anaemia seemed to be recovering at 75 days $\mathrm{PE}$ (mean $\mathrm{Hb} 2.8 \pm$ $0.4 \mathrm{~g} / 100 \mathrm{~mL}$ ). At 45 days $\mathrm{PE}$, the $\mathrm{Hb}$ of fish reared at $20^{\circ} \mathrm{C}$ was significantly lower than that at $8^{\circ} \mathrm{C}$ (Wilcoxon rank sum, $Z=2.59, p=0.009$ ). All anaemic fish had abnormally pale coloured gills and internal organs, espe- cially the liver. No anaemic fish were observed at $8^{\circ} \mathrm{C}$. Past studies have shown a strong correlation between the number of adult parasites and the host anaemic signs ${ }^{1,7)}$. The appearance of anaemic flounder in the present study also coincided with the parasite maturation. Thus, this evidences that the adult $N$. hirame is responsible for the anaemia of olive flounder. However, mass mortality of wild flounder due to $N$. hirame infection has never been reported. In the present study, $12.5 \%$ mortalities were observed at $20^{\circ} \mathrm{C}$ between 41 and 45 days PE, associated with anaemia. The worm intensity in the present study was within the range of infection level in wild juvenile flounder in Obama Bay (Shirakashi, unpublished data). Therefore, the present study provided potential evidence that $N$. hirame may cause mortalities of juvenile flounder in the wild as previously suggested ${ }^{2)}$.

\section{Acknowledgements}

We thank all members of Kamiura Station, National Center for Stock Enhancement. Thanks are also to Yukiyo Kojima and Dr. Nobuyuki Tsutsumi who assisted routine sampling. The research is funded by JSPS grant \# 15-11317.

\section{References}

1) Mushiake, K., K. Mori and M. Arimoto (2001): Fish Pathol., 36, 125-132. 2) Anshary, H., E. Yamamoto, T. Miyanaga and K. Ogawa (2002): Fish Pathol., 37, 131-140. 3) Tsutsumi, N., K. Mushiake, K. Mori, M. Arimoto, T. Yoshinaga and K. Ogawa (2002): Fish Pathol., 37, 41-47. 4) Yoshinaga, T., I. Segawa, T. Kamaishi and M. Sorimachi (2000): Fish Pathol., 35, 8588. 5) Tsutsumi, N., T. Yoshinaga, T. Kamaishi, C. Nakayasu and K. Ogawa (2003) Fish Pathol., 38, 41-47. 6) Anshary, H. and K. Ogawa (2001): Fish Pathol., 36, 21-26. 7) Yoshinaga, T., T. Kamaishi, I. Segawa, K. Yamano, H. Ikeda and M. Sorimachi (2001): Fish Pathol., 36, 13-20. 